This is a self-archived version of an original article. This version may differ from the original in pagination and typographic details.

Author(s): Leicht, Katja; Seppälä, Otto

Title: Direct and transgenerational effects of an experimental heatwave on early life stages in a freshwater snail

Year: 2019

Version: Published version

Copyright: @ 2019 The Authors

Rights: CC BY-NC 4.0

Rights url: https://creativecommons.org/licenses/by-nc/4.0/

Please cite the original version:

Leicht, K., \& Seppälä, O. (2019). Direct and transgenerational effects of an experimental heatwave on early life stages in a freshwater snail. Freshwater Biology, 64(12), 2131-2140. https://doi.org/10.1111/fwb.13401 


\title{
Direct and transgenerational effects of an experimental heatwave on early life stages in a freshwater snail
}

\author{
Katja Leicht ${ }^{1,2}$ | Otto Seppälä ${ }^{1,3,4}$ (I)
}

${ }^{1}$ Department of Aquatic Ecology, Swiss Federal Institute of Aquatic Science and Technology, Dübendorf, Switzerland

${ }^{2}$ Department of Biological and Environmental Science, University of Jyväskylä, Jyväskylä, Finland

${ }^{3}$ Institute of Integrative Biology, ETH Zürich, Zürich, Switzerland

${ }^{4}$ Research Department for Limnology, University of Innsbruck, Mondsee, Austria

\section{Correspondence}

Otto Seppälä, Research Department for Limnology, University of Innsbruck, Mondseestrasse 9, 5310 Mondsee, Austria. Email: otto.seppaelae@uibk.ac.at

Funding information

Biological Interactions Doctoral Program (BIOINT); Emil Aaltonen Foundation; Swiss National Science Foundation, Grant/Award Numbers: 31003A 140876 and 31003A 169531.

\begin{abstract}
1. Global climate change imposes a serious threat to natural populations of many species. Estimates of the effects of climate change-mediated environmental stresses are, however, often based only on their direct effects on organisms, and neglect the potential transgenerational (e.g. maternal) effects.

2. We tested whether high temperature (i.e. an experimental heatwave), which is known to reduce the performance of adult Lymnaea stagnalis snails, affects the produced offspring (eggs and hatchlings) through maternal effects, and how strong these effects are compared with the effects of direct exposure of offspring to high temperature. We examined the effect of maternal thermal environment $\left(15^{\circ} \mathrm{C}\right.$ versus $25^{\circ} \mathrm{C}$ ) on per offspring investment (egg size), and the role of both maternal and offspring thermal environments $\left(15^{\circ} \mathrm{C}\right.$ versus $\left.25^{\circ} \mathrm{C}\right)$ on hatching success and developmental time of eggs, offspring survival after hatching, and hatchling size at the age of 5 weeks.
\end{abstract}

3. Exposure of mothers to high temperature reduced the size of oviposited eggs, increased their hatching success, and also made the onset of hatching earlier. However, high maternal temperature reduced the survival and the final size of hatched juveniles. Direct exposure of offspring to high temperature reduced their survival (both eggs and hatchlings) but increased the developmental rate and growth of those individuals that survived. Interestingly, the magnitude of maternal effects on hatching success of eggs and hatchling survival were similar to the direct effects of high temperature.

4. Our results indicate that heatwaves can affect natural populations through transgenerational maternal effects and that the magnitude of those effects can be equally strong to the direct effects of temperature, although this depends on the trait considered. These findings highlight the importance of considering the transgenerational effects of climate warming when estimating its effects in the wild.

\section{KEYWORDS}

climate change, environmental stress, global warming, Lymnaea stagnalis, maternal effects 


\section{1 | INTRODUCTION}

Owing to global climate change, the average temperatures at the Earth's surface, as well as the frequency and severity of extreme weather events such as summer heatwaves, are increasing (Easterling et al., 2000; Karl \& Trenberth, 2003; Kirtman et al., 2013; Meehl \& Tebaldi, 2004; Stillman, 2019). These changes can have strong effects on organisms that escalate to higher levels of biological organisation such as populations and communities (Parmesan \& Yohe, 2003; Walther, 2010; Walther et al., 2002). Especially extreme weather events can dramatically influence population dynamics, species abundance, and species interactions (e.g. Bruno et al., 2007; Easterling et al., 2000; Hance, van Baaren, Vernon, \& Boivin, 2007). However, environmental conditions can not only influence the fitness of the individuals exposed to them but also the fitness of their offspring through transgenerational maternal and/or paternal ef fects (reviewed in Bernardo, 1996; Mousseau \& Fox, 1998b). Hence, for understanding the effects of climate change on natural populations, studies examining such transgenerational effects are needed.

In particular, transgenerational maternal effects after exposure to environmental stress can significantly alter offspring performance (e.g. Janhunen, Piironen, \& Peuhkuri, 2010; Mitchell \& Read, 2005; Silbermann \& Tatar, 2000). Such effects can result, for example, from the reduced physiological condition of the mother that limits the total amount of resources it invests in reproduction (Steer, Moltschaniwskyj, Nichols, \& Miller, 2004; Tessier, Henry, Goulden, \& Durand, 1983), exposure of offspring to hormones produced by the mother (Groothuis \& Schwabl, 2008; McCormick, 1999), and/or epigenetic effects (reviewed in Bonduriansky \& Day, 2018). Maternal effects could also take place via altered resource allocation between reproduction and other traits depending on the environmental conditions the mother experiences. Challenging environmental conditions may, for example, reduce resource allocation to produced offspring to sustain self-maintenance or increase per offspring investment when the reproductive value of individuals is changed so that investment in current reproduction increases at the expense of future reproduction (Fisher, 1930; Williams, 1966). Furthermore, maternal effects can be adaptations to prepare offspring for the future conditions they are about to encounter (e.g. herbivory, parasitism, pollution; Agrawal, 2002; Marshall, 2008; Moret, 2006).

To understand the consequences of such maternal effects in the context of climate change, it is essential to estimate their direction and magnitude compared with the direct effects of the same environmental factors. Maternal effects are typically strongest in the early stages of organisms' life histories (Heath, Fox, \& Heath, 1999; Mousseau \& Dingle, 1991; Pettay, Charmantier, Wilson, \& Lummaa, 2008), but such stages are often also highly susceptible to the direct effects of environmental variation (e.g. Jang, 1991; Klockmann, Günter, \& Fischer, 2017; Zhang, Chang, Hoffmann, Zhang, \& Ma, 2015). For example, temperature determines the development of eggs and juveniles by altering their metabolic and physiological processes in many species (Gillooly, Brown, West, Savage, \& Charnov, 2001; Person-Le Ruyet, Mahé, Le Bayon, \& Le Delliou, 2004; Zuo,
Moses, West, Hou, \& Brown, 2012). The high temperature, in particular, can impose a serious challenge by reducing the hatching success of eggs and early survival of hatched offspring (Janhunen et al., 2010; Klockmann et al., 2017; Zhang et al., 2015). Despite high interest on transgenerational effects of climate change in natural populations (reviewed in Donelson, Salinas, Munday, \& Shama, 2018), their relative importance compared with direct effects of the same environmental factors is, however, often overlooked (but see Burgess \& Marshall, 2011; Parker et al., 2012; Salinas \& Munch, 2012; Shama, Strobel, Mark, \& Wegner, 2014; Wadgymar, Mactavish, \& Anderson, 2018).

Here, we examined the role of transgenerational maternal effects in determining the performance of juvenile Lymnaea stagnalis L. (Gastropoda: Pulmonata) snails after exposure to an experimental heatwave. We tested which juvenile traits are affected by maternal effects and how strong these effects are compared with the effects of direct exposure of offspring to high temperature. In this species, exposure of adult individuals to high temperature $\left(\geq 25^{\circ} \mathrm{C}\right)$ initially increases growth and reproduction, but prolonged exposure (1 week or longer) ceases reproductive rate and reduces immune function (Leicht, Jokela, \& Seppälä, 2013; Seppälä \& Jokela, 2011). This indicates that high temperature is physiologically challenging and has strong negative effects on adult snails. We estimated the effect of maternal thermal environment $\left(15^{\circ} \mathrm{C}\right.$ versus $\left.25^{\circ} \mathrm{C}\right)$ on per offspring investment by adult snails (egg size), and the role of both maternal and offspring thermal environments on offspring performance (hatching success and developmental time of eggs, survival of hatched offspring, offspring size at the age of 5 weeks) using a full-factorial design. We hypothesised that high temperature would affect offspring performance both directly and through maternal effects. We expected, however, that the magnitude of direct effects would be stronger than maternal effects although their relative importance and the direction could vary among traits.

\section{METHODS}

\subsection{Experimental animals}

The snails used in this study came from a laboratory stock population ( $F_{4}$ generation) originating from a pond in Zurich, Switzerland $\left(47^{\circ} 22^{\prime} 05^{\prime \prime} \mathrm{N}, 8^{\circ} 34^{\prime} 41^{\prime \prime} \mathrm{E}\right)$. The summer water temperature in ponds typically remains low $\left(<16^{\circ} \mathrm{C}\right)$ in this region, although it depends on pond hydrology (T. Salo, unpublished data). However, during heatwaves, water temperature can rapidly increase to $20-30^{\circ} \mathrm{C}$ and remain high for over 2 weeks (T. Salo, unpublished data). We started the stock population using 45 adult snails collected from the pond. Since L. stagnalis prefers outcrossing (Nakadera, Mariën, Van Straalen, \& Koene, 2017; Puurtinen, Knott, Suonpää, Nissinen, \& Kaitala, 2007), often engages in multiple matings (Nakadera et al., 2017), and can store sperm from those matings for over 2 months (Nakadera, Blom, $\&$ Koene, 2014), the collected individuals probably carried alleles from a higher number of snails. We maintained the stock population in the approximate size of 400 individuals at $15 \pm 2{ }^{\circ} \mathrm{C}$ (control 
temperature used in the experiment; see the section about the experimental design below) for 2 years before the study (see Leicht, Seppälä, \& Seppälä, 2017). At the time of the experiment, the stock population showed genetic polymorphism typical for natural populations in northern Switzerland (Leicht, Jokela, \& Seppälä, 2019).

We haphazardly collected 113 adult snails from the stock population and used them as a maternal generation in the experiment. We placed the snails individually in 2-dL perforated plastic cups sunk into a water bath (aged tap water at $15 \pm 1^{\circ} \mathrm{C}$ ) that was connected to a biological filter. We used a water bath to provide maximal water quality for snails. This minimises the growth of microorganisms in water that activate snail immune functions (Seppälä \& Leicht, 2013). This is important because immune challenges could potentially alter snail reproductive strategy and/or affect the quality of produced offspring. We fed the snails with fresh lettuce ad libitum and maintained them under these conditions for 3 days prior to the experiment to acclimate them to the maintenance conditions. Because L. stagnalis snails can reproduce through self-fertilisation as well as through outcrossing using allosperm they have stored from previous matings (Cain, 1956; Nakadera et al., 2014), experimental snails did not need a mating partner to oviposit eggs under the experimental conditions.

\section{2 | Experimental design}

\subsection{1 | Maternal treatments}

At the beginning of the experiment, we randomly assigned the snails used as a maternal generation (see the previous section) into two temperature treatments [ $15 \pm 1^{\circ} \mathrm{C}$ (54 snails), $25 \pm 1^{\circ} \mathrm{C}$ (59 snails); Figure 1]. We used $25^{\circ} \mathrm{C}$ as a high (i.e. heatwave) temperature as it reduces immune defence and life history traits in adult snails (Leicht

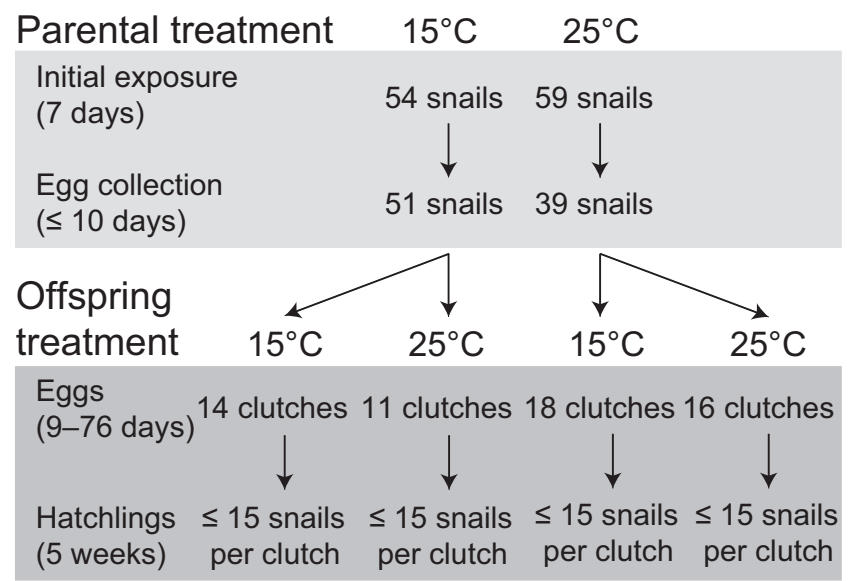

FIGURE 1 Summary of the full-factorial experimental design used to examine direct and transgenerational maternal effects of exposure to two temperatures (benign: $15^{\circ} \mathrm{C}$; heatwave: $25^{\circ} \mathrm{C}$ ) in Lymnaea stagnalis snails. One egg clutch per parental snail was used in offspring treatments. When available, 15 hatchlings per egg clutch were used. When fewer individuals were available, they were all used et al., 2013; Seppälä \& Jokela, 2011), lies above the thermal optimum for development and growth of juvenile snails (Vaughn, 1953), and occurs intermittently in habitats of snails during hot summers (T. Salo, unpublished data). We chose $15^{\circ} \mathrm{C}$ as a control temperature as it is close to the thermal optimum of L. stagnalis (Vaughn, 1953) and common in ponds (T. Salo, unpublished data). Note that we assigned more individuals into the high-temperature treatment because we expected increased mortality in those snails. We transferred the snails to their treatment temperatures in cups filled with aged tap water at $15^{\circ} \mathrm{C}$. This allowed a slow change ( $>10 \mathrm{hr}$ ) to the target temperature for snails assigned to the high-temperature treatment. We then transferred the snails into perforated plastic cups (2 dL) sunk into similar water baths as above, and exposed them to their respective temperature treatments for 7 days. At $15^{\circ} \mathrm{C}, 51$ of these snails survived, and of those 25 oviposited eggs. At $25^{\circ} \mathrm{C}, 39$ snails survived, and 34 of them reproduced. We did not measure the number of oviposited eggs in this experiment as the effect of temperature on snail fecundity has been described in detail in earlier studies (Leicht et al., 2013, 2017).

After the initial 7-day exposure to temperature treatments, we removed all egg clutches oviposited by the snails from the cups and continued maintaining the snails under the same experimental conditions. During the following 10 days, we checked the cups twice a day for new clutches to be collected for the next step of the experiment (see the next section). This procedure ensured, first, that the snails were exposed to their respective temperature treatments long enough to induce strong effects on their performance before the clutches were collected (see Leicht et al., 2013) and, second, that the collected clutches were exposed to the maternal temperature treatments only briefly. From each snail that oviposited (same individuals as above reproduced), we collected the first clutch containing more than 20 eggs, or if only smaller clutches were produced, the largest clutch. We placed each collected clutch on paper with a millimetre grid and photographed it from $10 \mathrm{~cm}$ above with a Fujifilm FinePix F30 digital camera (scene mode: close up, focal length: $35 \mathrm{~mm}$, aperture: $\mathrm{F} / 2.8$, shutter speed: 1/85, sensitivity: ISO-200, image size: $2848 \times 2136$ pixels, focus mode: autofocus). From the digital images, we counted the eggs in each clutch. Furthermore, we measured the two-dimensional area $\left(\mathrm{mm}^{2}\right)$ of five randomly chosen eggs in each clutch from the digital images using ImageJ software (ImageJ 1.42q; Wayne Rasband, National Institute of Health, USA). After photographing, we placed the clutches individually into plastic cups with $0.4 \mathrm{dL}$ of aged tap water to be transferred to the next step of the experiment (see the next section). It is important to note that the time different snails needed for ovipositing after the initial exposure period varied between 1 and 10 days, which may have affected the thermal challenge imposed to them as well as their offspring. However, to our knowledge, oviposition cannot be induced artificially in this species.

\subsection{2 | Offspring treatments}

We used a full-factorial design to expose egg clutches produced in both maternal temperature treatments (see the previous section) to 
two offspring temperature treatments $\left(15^{\circ} \mathrm{C}, 25^{\circ} \mathrm{C}\right.$; Figure 1$)$. In each maternal temperature treatment, we randomly assigned some of the oviposited egg clutches to remain at the same temperature where they were produced and transferred the rest of the clutches to the other temperature (note that splitting each clutch into both treatments was not possible because eggs require an intact egg clutch to develop). The number of egg clutches per treatment combination varied between 11 and 18, which was because of unequal mortality and probability to reproduce in parental snails in different treatments (see the previous section). We slowly warmed up or cooled down the clutches that were transferred to a different temperature as described above to avoid a sudden change between temperatures. After that, we checked the clutches daily, counted the number of hatched snails (i.e. snails that had left the clutches), and removed the hatchlings from the cups. When possible, we placed 15 hatchlings from each clutch individually in plastic cups filled with $0.4 \mathrm{dL}$ of aged tap water. We used all hatchlings when $<15$ individuals were available. We fed the snails with Spirulina ad libitum and changed the water in the cups twice a week. We reared the isolated hatchlings for 5 weeks and measured their survival and shell length to the nearest $0.1 \mathrm{~mm}$ using a digital calliper at the end of the experiment.

It is important to note that the main aim of our experiment was to evaluate the relative importance of direct and transgenerational maternal effects in determining snail performance under different temperature conditions. Furthermore, we focused on traits that are closely linked to fitness (survival, size; Langeloh, Behrmann-Godel, \& Seppälä, 2017). Therefore, we did not split the offspring from each clutch into different temperature treatments after hatching and also did not measure their growth trajectories in detail. These aspects would, however, be interesting to investigate in future studies. This is, for instance, because in our study species, exposure of embryos to predator cues leads to a reduced hatchling size followed by compensatory growth during their early development (Dalesman, Thomas, \& Rundle, 2015).

\section{3 | Statistical analyses}

We analysed the effect of temperature on the survival of adult snails during the initial exposure to experimental treatments (a 7-day period before the collection of egg clutches started) using a generalised linear model. We used the status of snails (survived, died) as a binomial response variable (logit link function) and temperature treatment as a fixed factor. Additionally, we analysed variation in snail reproductive status (oviposited, did not oviposit) using a similar generalised linear model. We analysed the effect of temperature on the size of produced eggs (In transformed to homogenise error variance) using a mixed-model analysis of variance (mixed-model ANOVA). In the analysis, we used a model with maternal temperature treatment as a fixed and the clutch from which each egg originated as a random factor (nested within maternal temperature).

To estimate the effects of maternal and offspring temperature on offspring performance, we first analysed the variation in hatching success of eggs using a generalised linear model. In the analysis, we used the proportion of eggs that hatched from each clutch as a binomial response variable (logit link function), and maternal temperature treatment and offspring temperature treatment as fixed factors. We included the interaction term between the factors into the model. Fewer than three snails hatched from two clutches that were both produced and maintained at $25^{\circ} \mathrm{C}$. We excluded these individuals from all the further analyses as they would not provide sufficient replication within those clutches.

After that, we calculated the developmental time until hatching for each egg as the difference between the date the clutch was oviposited and the hatching date. We then analysed the effects of temperature on developmental time using a multivariate analysis of variance (MANOVA, with Pillai's trace test statistic for unequal sample sizes). We used the onset of hatching (i.e. the first hatching day; square-root transformed to homogenise error variance), median developmental time (we used the median rather than the mean as the distribution of hatching time within the clutches was skewed), and the end of hatching (i.e. the last hatching day; In transformed to homogenise error variance) for each clutch as response variables. We included the onset and the end of hatching into the analysis in addition to the median developmental time to more completely examine the overall hatching dynamics. We used maternal temperature treatment and offspring temperature treatment as fixed factors in the analysis and included the interaction term between them into the model. Since the MANOVA indicated effects of temperature on developmental time (see the results section), we conducted separate ANOVAs using a similar model as above for the different parameters of developmental time to investigate whether their responses to temperature were different.

We analysed the variation in the survival of hatched offspring during the experiment using a generalised linear mixed-effects model with the status of snails (survived, died) as a binomial response variable (logit link function). We used maternal temperature treatment and offspring temperature treatment as fixed factors, and egg clutch from which each offspring originated as a random factor (nested within the interaction between maternal temperature and offspring temperature). We included the interaction term between maternal and offspring temperature into the model. From the offspring that survived until the end of the experiment, we analysed the variation in size using a mixed-model ANOVA with shell length (square-root transformed to homogenise error variance) as a response variable, and a similar model as for survival. Survival and/or size could not be measured from 30 juvenile snails (3.5\% of all individuals) because of human errors. We excluded these snails from the data. The assumptions of all the above analyses were fulfilled, and we performed them using IBM SPSS Statistics Version 23.0 software (Armonk, NY: IBM Corp.).

\section{3 | RESULTS}

During the initial exposure of adult snails to different temperature treatments (i.e. a 7-day period before the collection of egg clutches 
started), the survival of snails exposed to $25^{\circ} \mathrm{C}$ was reduced (estimated marginal mean \pm SE: $66.1 \pm 6.2 \%$ ) compared with snails exposed to $15^{\circ} \mathrm{C}$ (estimated marginal mean \pm SE: $94.4 \pm 3.1 \%$; generalised linear model: Wald $\left.\chi^{2}=10.940, d f=1, p=0.001\right)$. In those snails that survived, the probability of reproducing was higher at $25^{\circ} \mathrm{C}$ (estimated marginal mean \pm SE: $87.2 \pm 5.4 \%$ ) than at $15^{\circ} \mathrm{C}$ (estimated marginal mean $\pm S E: 49.0 \pm 7.0 \%$; generalised linear model: Wald $\chi^{2}=12.429, d f=1, p<0.001$ ). Note that the same individuals that reproduced during this initial exposure period also produced the eggs that were exposed to offspring temperature treatments.

Eggs oviposited by snails at $25^{\circ} \mathrm{C}$ were smaller than those oviposited at $15^{\circ} \mathrm{C}$ (two-dimensional area; estimated marginal mean $\pm S E: 25^{\circ} \mathrm{C}: 1.11 \pm 0.01 \mathrm{~mm}^{2} ; 15^{\circ} \mathrm{C}: 1.30 \pm 0.01 \mathrm{~mm}^{2}$; ANOVA: $\left.F_{1,57}=26.275, p<0.001\right)$. Hatching success of eggs was affected by both the maternal temperature treatment and the offspring temperature treatment, and these effects were independent of each other (Table 1, Figure 2). High maternal temperature increased hatching success by $9.0 \%$ whereas high offspring temperature reduced it by $7.5 \%$ (Figure 2). Maternal and offspring temperature also affected the developmental time of eggs, and these effects were independent of each other (MANOVA, maternal temperature treatment: Pillai's trace $=0.310, F_{3,51}=7.654, p$ $<0.001$; offspring temperature treatment: Pillai's trace $=0.918$, $F_{3,51}=191.413, p<0.001$; maternal temperature treatment $\times$ offspring temperature treatment: Pillai's trace $=0.046, F_{3,51}=0.827$, $p=0.485$ ). The effects of temperature on developmental time were first because offspring started to hatch $12.3 \%$ earlier when mothers had been exposed to $25^{\circ} \mathrm{C}$ (ANOVA: $F_{1,53}=15.806$, $p<0.001$; Figure 3). Second, the onset, median, and the end of hatching were earlier when offspring were maintained at $25^{\circ} \mathrm{C}$ (first day of hatching: 55.1\% reduction; ANOVA: $F_{1,53}=571.961$, $p<0.001$; median developmental time: $43.8 \%$ reduction; ANOVA: $F_{1,53}=189.817, p<0.001$; last day of hatching: $43.8 \%$ reduction; ANOVA: $F_{1,53}=62.002, p<0.001$; Figure 3).

High maternal temperature reduced offspring survival by $17.8 \%$, and this effect was independent of the temperature offspring were exposed to (Table 2, Figure 4a). When offspring were maintained at $25^{\circ} \mathrm{C}$, they showed a tendency towards lower survival (Table 2 , Figure 4a). Temperature affected the size of offspring so that high maternal temperature and low offspring temperature reduced shell length at the end of the experiment (Table 3, Figure $4 \mathrm{~b}$ ).

TAB LE 1 Generalised linear model for the hatching success of Lymnaea stagnalis eggs (proportion of eggs that hatched per clutch) by maternal temperature treatment $\left(15,25^{\circ} \mathrm{C}\right)$, offspring temperature treatment $\left(15,25^{\circ} \mathrm{C}\right)$, and their interaction

\begin{tabular}{llll} 
Effect & $d f$ & Wald- $\chi^{2}$ & $p$ \\
\hline $\begin{array}{l}\text { Maternal temperature treat- } \\
\text { ment (M) }\end{array}$ & 1 & 29.992 & $<0.001$ \\
$\begin{array}{l}\text { Offspring temperature } \\
\text { treatment (O) }\end{array}$ & 1 & 24.833 & $<0.001$ \\
$M \times O$ & 1 & 0.377 & 0.539 \\
\hline
\end{tabular}

\section{4 | DISCUSSION}

Exposure to an experimental heatwave affected eggs and hatchlings of $L$. stagnalis snails both directly and via transgenerational maternal effects. Direct effects of high temperature were both negative and positive depending on the examined trait. Exposure to high temperature reduced the hatching success of eggs but it increased the development rate and the subsequent growth of those individuals that hatched. The magnitude and the direction of maternal effects when compared with direct effects varied among examined traits. In general, high maternal temperature benefitted offspring at very early life stages (hatching success and the onset of hatching), but reduced performance at later stages (survival and final size of hatched snails). Hence, the potential adaptive value of responding to high temperature by maternal effects may be limited only to very early life stages. Interestingly, the magnitude of maternal effects on hatching success

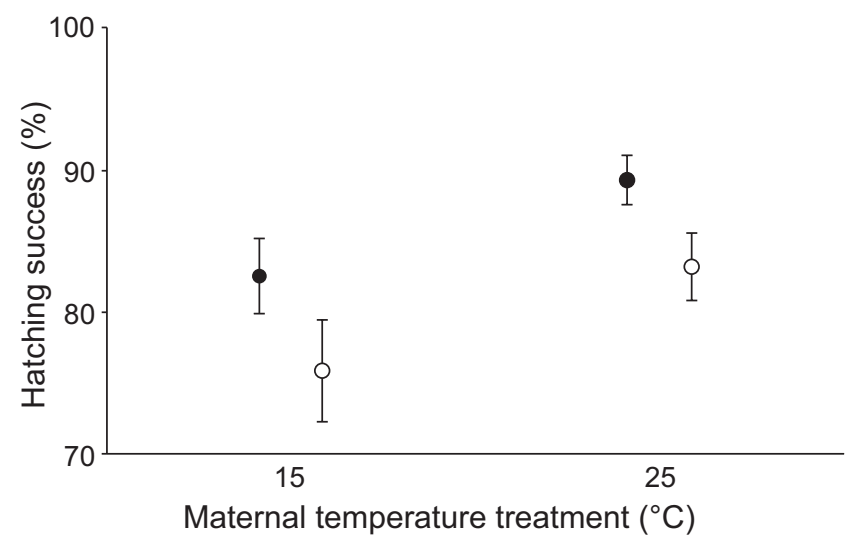

FIGURE 2 Hatching success of eggs (proportion of eggs that hatched [\%; mean $\pm 95 \%$ confidence interval]) for egg clutches produced at different maternal temperature treatments $\left(15,25^{\circ} \mathrm{C}\right)$ and maintained at $15^{\circ} \mathrm{C}$ (black circles) or at $25^{\circ} \mathrm{C}$ (white circles)

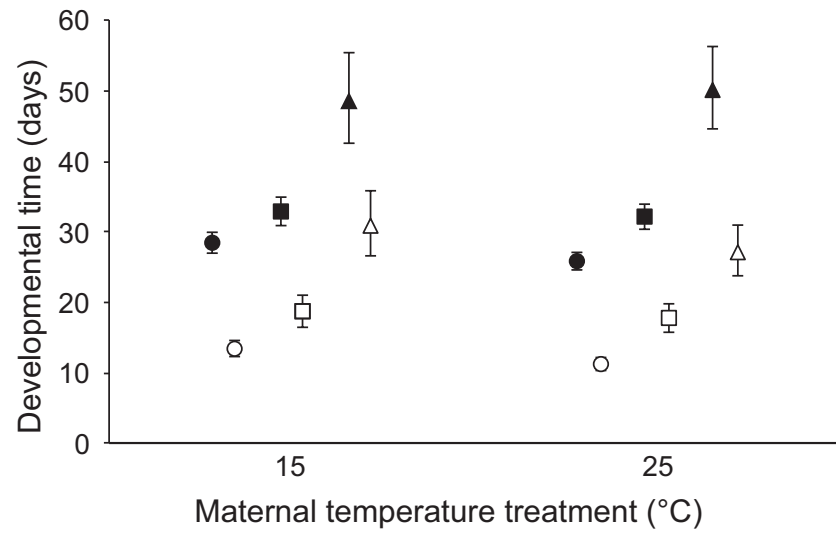

FIGURE 3 Developmental time of eggs presented using the mean ( $\pm 95 \%$ confidence interval) of onset of hatching (circles), median developmental time (squares), and end of hatching (triangles) for egg clutches produced at different maternal temperature treatments $\left(15,25^{\circ} \mathrm{C}\right.$ ) and maintained at $15^{\circ} \mathrm{C}$ (black symbols) or at $25^{\circ} \mathrm{C}$ (white symbols) 


\begin{tabular}{lllllll} 
Effect & df & $F$ & Estimate & SD & $Z$ & $p$ \\
\hline Maternal temperature treatment (M) & 1 & 4.452 & & & & 0.035 \\
Offspring temperature treatment (O) & 1 & 3.588 & & & & 0.059 \\
$M \times O$ & 1 & 1.587 & & & & 0.208 \\
\hline Egg clutch $(\mathrm{M} \times \mathrm{O})$ & & & 0.582 & 0.184 & 3.165 & 0.002
\end{tabular}

TAB LE 2 Generalised linear mixedeffects model for the survival of juvenile L. stagnalis snails during the experiment (survived/died) by maternal temperature treatment $\left(15,25^{\circ} \mathrm{C}\right)$, offspring temperature treatment $\left(15,25^{\circ} \mathrm{C}\right)$, their interaction, and the egg clutch from which each individual originated
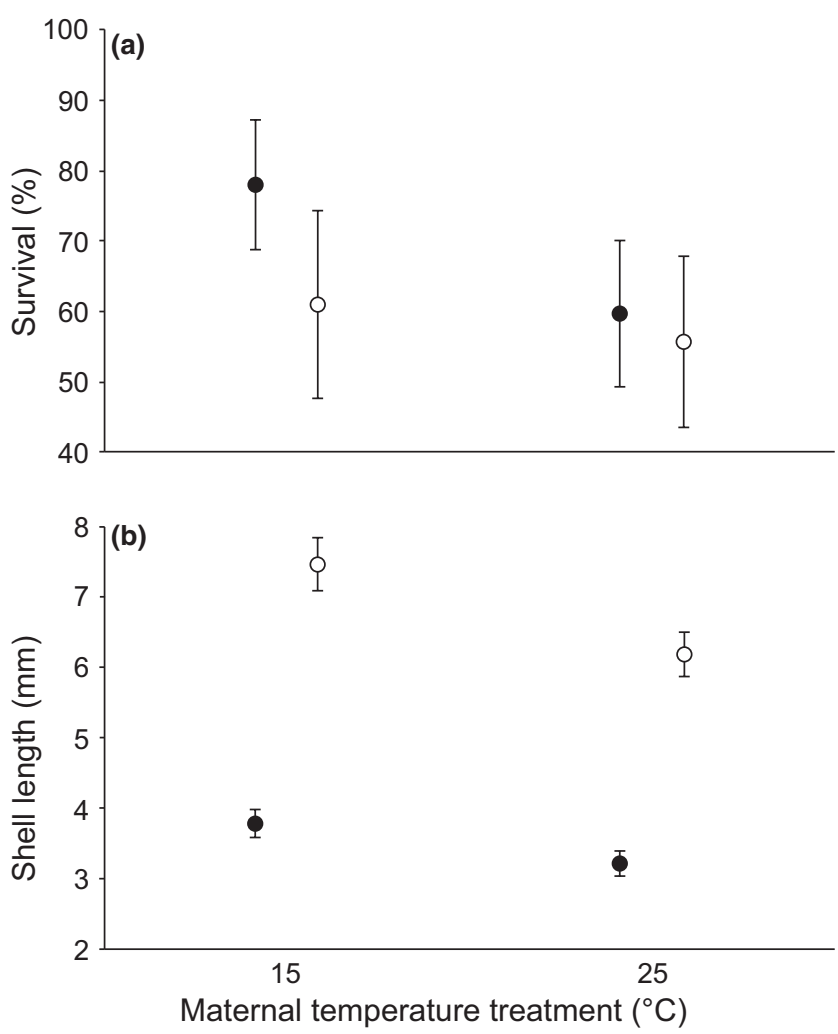

FIGURE 4 (a) Proportion (\%; estimated marginal mean $\pm 95 \%$ confidence interval) of offspring that survived until the end of the experiment, and (b) shell length ( $\mathrm{mm}$; estimated marginal mean $\pm 95 \%$ confidence interval) of those snails at the end of the experiment when produced at different maternal temperature treatments $\left(15,25^{\circ} \mathrm{C}\right)$ and maintained at $15^{\circ} \mathrm{C}$ (black circles) or at $25^{\circ} \mathrm{C}$ (white circles)

TAB LE 3 Mixed-model analysis of variance for the shell length of juvenile L. stagnalis snails at the end of the experiment by maternal temperature treatment $\left(15,25^{\circ} \mathrm{C}\right)$, offspring temperature treatment $\left(15,25^{\circ} \mathrm{C}\right)$, their interaction, and the clutch from which each individual originated

\begin{tabular}{|llccl|}
\hline Effect & $d f$ & MS & $F$ & $p$ \\
\hline $\begin{array}{l}\text { Maternal temperature } \\
\text { treatment }(\mathrm{M})\end{array}$ & 1 & 3.926 & $15.012^{\mathrm{a}}$ & $<0.001$ \\
\hline $\begin{array}{l}\text { Offspring temperature } \\
\text { treatment }(\mathrm{O})\end{array}$ & 1 & 54.520 & $208.927^{\mathrm{a}}$ & $<0.001$ \\
\hline $\mathrm{M} \times \mathrm{O}$ & 1 & 0.216 & $0.827^{\mathrm{a}}$ & 0.367 \\
\hline Egg clutch $(\mathrm{M} \times \mathrm{O})$ & 53 & 0.302 & 3.370 & $<0.001$ \\
\hline Error & 455 & 0.090 & & \\
\hline
\end{tabular}

Egg clutch $(\mathrm{M} \times \mathrm{O})$ as the error term. and survival of offspring were similar to the direct effects of high temperature, although in the case of hatching success the direction of the effects differed. These findings indicate that heatwaves can not only impact natural populations through maternal effects but that the magnitude of those effects can be equally strong to the direct within generation effects of high temperature. The relative strength of the direct and maternal effects, however, depends on the trait considered.

It is important to note that because not all parental snails that we initially exposed to different temperatures survived or reproduced, potential differences between the temperature treatments in offspring generation could arise from selection in the parental population. This could be, for instance, if weak snails could not survive under environmental stress. Similarly, not all offspring hatched or they died before the end of the experiment. While we cannot exclude or estimate the potential role of selection in our experiment, it seems unlikely that selection could explain our results on maternal effects. This is because the longest lasting effects of high maternal temperature on offspring (i.e. hatchling survival and size at the end of the experiment) were negative. If only high-quality individuals were able to survive and reproduce at the high temperature, this should lead to the opposite result. Because high temperature had a direct negative effect on the hatching of juvenile snails, their increased size at the end of the experiment could be not only due to phenotypic plasticity but also because of selection.

\subsection{Effects of temperature on eggs}

Mothers exposed to high temperature produced smaller eggs that had higher hatching success compared with snails that oviposited at the benign temperature $(14.6 \%$ reduction in size, $9.0 \%$ increase in hatching success). Thus, exposure of the maternal generation to high temperature can increase the quality of produced eggs despite their smaller size. The high maternal temperature made the onset of hatching earlier by 2.5 days (12.3\% reduction). The magnitude of the direct effect of high temperature on the hatching success of eggs was similar to the observed maternal effect, but negative $(7.5 \%$ reduction). The direct effect of high temperature on the development of eggs was strong by shortening the median developmental time by approximately 2 weeks (43.8\% reductions). Faster development and earlier hatching could reduce the risk of eggs being exposed to natural enemies such as predators (see Chivers et al., 2001; Warkentin, 1995), and it is suggested to increase future survival of offspring (Arcese \& Smith, 1985; Warner \& Shine, 2007) as well as 
allow earlier maturation and increased reproductive output (Uller \& Olsson, 2010). However, early hatching may also bring disadvantages by leading to less well-developed offspring (e.g. Buckley, Michael, \& Irschick, 2005; Warkentin, 1999).

Large egg size is often beneficial for offspring by increasing their fitness (Fox, 1994; Hutchings, 1991; Krist, 2011). This is likely to be because large eggs can provide more energy and nutrients for developing embryos (reviewed in Williams, 1994). In aquatic organisms, however, reduced egg size may be beneficial by ensuring oxygen supply to embryos when the oxygen concentration in water decreases under high temperature (Moran \& Woods, 2007; Woods, 1999). Therefore, egg size might not be a good indicator of egg quality. The observed maternal effects on the development of eggs (developmental time and hatching success) may be due to two non-exclusive mechanisms. First, high temperature can increase the metabolic rate of adults that allow the production of high-quality eggs (see Jann \& Ward, 1999; Saino, Romano, Ambrosini, Ferrari, \& Møller, 2004). Second, it may increase resource allocation towards reproduction rather than other traits (e.g. growth) when the residual reproductive value of individuals decreases, for example, due to increased mortality (Fisher, 1930; Williams, 1966). The effect of maternal temperature on the developmental time of eggs was, however, limited to the onset of hatching. This possibly indicates that the increased investment on oviposited eggs may be rapidly depleted. By contrast, smaller eggs are expected to develop more slowly (Levitan, 2000). Therefore, it is possible that high maternal investment and small egg size over-rode each other's effects so that no net change in developmental time of eggs could be detected. The direct effect of temperature on hatching success of eggs is likely to be due to the high sensitivity of mollusc embryos to high temperature (Vaughn, 1953), which leads to mortality in several taxa probably due to denaturation of proteins (reviewed in Noble, Stenhouse, \& Schwanz, 2018; Pepin, 1991). The direct effect of temperature on the developmental time of eggs was possibly because temperature determines the speed of biochemical processes of the developing embryos (e.g. García-Guerrero, Villarreal, \& Racotta, 2003; Sibert, Ouellet, \& Brêthes, 2004).

\subsection{Effects of temperature on hatchlings}

Exposure of mothers to high temperature reduced the probability of offspring to survive until the age of 5 weeks (17.8\% reduction compared with $15^{\circ} \mathrm{C}$ ). High maternal temperature also reduced the size offspring reached (28.9\% reduction). High temperature showed a tendency to have a negative direct effect on offspring survival (16.1\% reduction). However, offspring that survived grew larger at high temperature ( $97.4 \%$ increase in size). Hence, high maternal temperature reduced offspring performance in the examined traits while the direct exposure of offspring to high temperature had both positive and negative effects. Reduced size of offspring due to high maternal temperature may lead to delayed maturity as well as reduced mating success and fecundity (reviewed in Clutton-Brock, 1988), and also increase susceptibility to predators (e.g. Craig, Burke,
Crowder, \& Rice, 2006; Janzen, 1993). Instead, the direct effect of high temperature can benefit those individuals that are able to survive under such conditions.

Reduced offspring size when mothers experience high temperature is found across a wide range of animal taxa (reviewed in Atkinson, Morley, Weetman, \& Hughes, 2001). The reason for this is not yet clear and may either be an adaptation to maximise mother's lifetime fitness (Yampolsky \& Scheiner, 1996) or due to physiological constraints under such conditions (Blanckenhorn, 2000). The direct effect of high temperature on offspring survival may be due to temperature-induced changes in, for instance, protein structures and/or membrane fluidity (reviewed in Pörtner, Lucassen, \& Storch, 2005), which can lead to body malfunctions and increased mortality. By contrast, high temperature fastens metabolic rate and can increase the growth of organisms (e.g. Iguchi \& Ikeda, 2005; Salo, Stamm, Burdon, Räsänen, \& Seppälä, 2017). This, however, could also lead to faster use of energetic reserves that may reduce survival.

\section{3 | General conclusions}

Our finding that the potential adaptive value of responding to high temperature by transgenerational maternal effects was limited to very early life stages (i.e. eggs) is in line with earlier research (Heath et al., 1999; Mousseau \& Dingle, 1991; Pettay et al., 2008). Instead, the result of equally strong direct and maternal effects on some of the examined traits when exposed to high temperature contradict earlier studies that have examined their relative importance in determining offspring performance and physiology (e.g. Burgess \& Marshall, 2011; Groeters \& Dingle, 1988; Huey, Wakefield, Crill, \& Gilchrist, 1995; Salinas \& Munch, 2012; Shama et al., 2014; Steigenga \& Fischer, 2007). In those studies, transgenerational effects of temperature are typically reported to be weak compared with its direct effects. To our knowledge, transgenerational effects of environmental change have been found to be strong compared with its direct effects in a climate change context only in germination probability of a perennial forb, Boechera stricta, when wintering conditions are manipulated (Wadgymar et al., 2018). Together with that finding, our results indicate that climate change-mediated environmental changes can affect natural populations through transgenerational effects and that these effects may be as strong as or even stronger than the direct effects of environmental change.

Despite high interest in transgenerational effects of climate change-mediated environmental change on organisms (Donelson et al., 2018), many studies have not tested their relative importance compared with direct within generation effects. This is because earlier studies have focused, for example, on testing whether negative effects of environmental change are reduced if parents have experienced the same environmental conditions (e.g. Donelson, Munday, McCormick, \& Pitcher, 2012; Miller, Watson, Donelson, McCormick, $\&$ Munday, 2012). Testing this does not necessarily require a full-factorial design that is needed for examining the relative importance of direct and transgenerational effects. The alternative approach is relevant in systems where the environment changes gradually and 
relatively slowly to a predicted direction (e.g. in oceans). Such studies would, however, not be realistic in terrestrial and freshwater systems that experience high and rapid fluctuations in several environmental conditions owing to extreme weather events such as heatwaves. In marine species, exposing parents to altered environmental conditions has been found to reduce the negative effects of increased temperature and $\mathrm{CO}_{2}$-level on offspring (Donelson et al., 2012; Miller et al., 2012; Shama et al., 2014). In our study, none of the observed direct effects of temperature depended on the maternal environment, which was indicated by the lack of interactive effects between temperature treatments. This may be due to higher unpredictability of extreme weather events in freshwater systems compared with marine environments that could limit the ability of such adaptive maternal effects to evolve (see Mousseau \& Fox, 1998a).

\section{ACKNOWLEDGMENTS}

We thank K. Räsänen and J. Jokela for constructive comments on the manuscript. The preprint of this article has been reviewed and recommended by Peer Community In Ecology (https://doi. org/10.24072/pci.ecology.100015). The study was funded by the Biological Interactions Doctoral Program (BIOINT) to KL and the Emil Aaltonen Foundation and the Swiss National Science Foundation (grant 31003A 140876 and 31003A 169531) to OS. The work conforms to the legal requirements of Switzerland.

\section{CONFLICT OF INTEREST}

The authors declare that they have no conflict of interest.

\section{DATA AVAILABILITY}

Data are available online: https://doi.org/10.5281/zenodo.2600811

\section{ORCID}

Otto Seppälä (iD https://orcid.org/0000-0001-7902-3069

\section{REFERENCES}

Agrawal, A. A. (2002). Herbivory and maternal effects: Mechanisms and consequences of transgenerational induced plant resistance. Ecology, 83, 3408-3415. https://doi.org/10.2307/3072089

Arcese, P., \& Smith, J. N. M. (1985). Phenotypic correlates and ecological consequences of dominance in song sparrows. Journal of Animal Ecology, 54, 817-830. https://doi.org/10.2307/4380

Atkinson, D., Morley, S. A., Weetman, D., \& Hughes, R. N. (2001). Offspring size responses to maternal temperature in ectotherms. In D. Atkinson, \& M. Thorndyke (Eds.), Environment and animal development: Genes, life histories and plasticity (pp. 269-285). Oxford: BIOS Scientific.

Bernardo, J. (1996). Maternal effects in animal ecology. American Zoologist, 36, 83-105. https://doi.org/10.1093/icb/36.2.83

Blanckenhorn, W. U. (2000). Temperature effects on egg size and their fitness consequences in the yellow dung fly Scathophaga stercoraria. Evolutionary Ecology, 14, 627-643. https://doi.org/10.1023/a:10109 11017700
Bonduriansky, R., \& Day, T. (2018). Extended heredity: A new understanding of inheritance and evolution. Princeton, NJ: Princeton University Press.

Bruno, J. F., Selig, E. R., Casey, K. S., Page, C. A., Willis, B. L., Harvell, C. D., \& Melendy, A. M. (2007). Thermal stress and coral cover as drivers of coral disease outbreaks. Plos Biology, 5, 1220-1227. https://doi. org/10.1371/journal.pbio.0050124

Buckley, C. R., Michael, S. F., \& Irschick, D. J. (2005). Early hatching decreases jumping performance in a direct-developing frog, Eleutherodactylus coqui. Functional Ecology, 19, 67-72. https://doi. org/10.1111/j.0269-8463.2005.00931.x

Burgess, S. C., \& Marshall, D. J. (2011). Temperature-induced maternal effects and environmental predictability. Journal of Experimental Biology, 214, 2329-2336. https://doi.org/10.1242/jeb.054718

Cain, G. L. (1956). Studies on cross-fertilization and self-fertilization in Lymnaea stagnalis appressa Say. Biological Bulletin, 111, 45-52. https ://doi.org/10.2307/1539182

Chivers, D. P., Kiesecker, J. M., Marco, A., DeVito, J., Anderson, M. T., \& Blaustein, A. R. (2001). Predator-induced life history changes in amphibians: Egg predation induces hatching. Oikos, 92, 135-142. https ://doi.org/10.1034/j.1600-0706.2001.920116.x

Clutton-Brock, T. H. (1988). Reproductive success studies of individual variation in contrasting breeding systems. Chicago, IL: University of Chicago Press.

Craig, J. K., Burke, B. J., Crowder, L. B., \& Rice, J. A. (2006). Prey growth and size-dependent predation in juvenile estuarine fishes: Experimental and model analyses. Ecology, 87, 2366-2377. https:// doi.org/10.1890/0012-9658(2006) 87[2366:Pgaspi]2.0.Co;2

Dalesman, S., Thomas, A., \& Rundle, S. D. (2015). Local adaptation and embryonic plasticity affect antipredator traits in hatchling pond snails. Freshwater Biology, 60, 663-672. https://doi.org/10.1111/ fwb.12512

Donelson, J. M., Munday, P. L., McCormick, M. I., \& Pitcher, C. R. (2012). Rapid transgenerational acclimation of a tropical reef fish to climate change. Nature Climate Change, 2, 30-32. https://doi.org/10.1038/ nclimate1323

Donelson, J. M., Salinas, S., Munday, P. L., \& Shama, L. N. S. (2018). Transgenerational plasticity and climate change experiments: Where do we go from here? Global Change Biology, 24, 13-34. https://doi. org/10.1111/gcb.13903

Easterling, D. R., Meehl, G. A., Parmesan, C., Changnon, S. A., Karl, T. R., \& Mearns, L. O. (2000). Climate extremes: Observations, modeling, and impacts. Science, 289, 2068-2074. https://doi.org/10.1126/scien ce.289.5487.2068

Fisher, R. A. (1930). The genetical theory of natural selection. Oxford: Clarendon Press.

Fox, C. W. (1994). The influence of egg size on offspring performance in the seed beetle, Callosobruchus maculatus. Oikos, 71, 321-325. https ://doi.org/10.2307/3546280

García-Guerrero, M., Villarreal, H., \& Racotta, I. S. (2003). Effect of temperature on lipids, proteins, and carbohydrates levels during development from egg extrusion to juvenile stage of Cherax quadricarinatus (Decapoda: Parastacidae). Comparative Biochemistry and Physiology a-Molecular \& Integrative Physiology, 135, 147-154. https:// doi.org/10.1016/s1095-6433(02)00354-9

Gillooly, J. F., Brown, J. H., West, G. B., Savage, V. M., \& Charnov, E. L. (2001). Effects of size and temperature on metabolic rate. Science, 293, 2248-2251. https://doi.org/10.1126/scien ce.1061967

Groeters, F. R., \& Dingle, H. (1988). Genetic and maternal influences on life-history plasticity in milkweed bugs (Oncopeltus): Response to temperature. Journal of Evolutionary Biology, 1, 317-333. https://doi. org/10.1046/j.1420-9101.1988.1040317.x

Groothuis, T. G. G., \& Schwabl, H. (2008). Hormone-mediated maternal effects in birds: Mechanisms matter but what do we know of them? 
Philosophical Transactions of the Royal Society B, 363, 1647-1661. https://doi.org/10.1098/rstb.2007.0007

Hance, T., van Baaren, J., Vernon, P., \& Boivin, G. (2007). Impact of extreme temperatures on parasitoids in a climate change perspective. Annual Review of Entomology, 52, 107-126. https://doi.org/10.1146/ annurev.ento.52.110405.091333

Heath, D. D., Fox, C. W., \& Heath, J. W. (1999). Maternal effects on offspring size: Variation through early development of chinook salmon. Evolution, 53, 1605-1611. https://doi.org/10.2307/2640906

Huey, R. B., Wakefield, T., Crill, W. D., \& Gilchrist, G. W. (1995). Withinand between-generation effects of temperature on early fecundity of Drosophila melanogaster. Heredity, 74, 216-223. https://doi. org/10.1038/hdy.1995.30

Hutchings, J. A. (1991). Fitness consequences of variation in egg size and food abundance in brook trout Salvelinus fontinalis. Evolution, 45 , 1162-1168. https://doi.org/10.2307/2409723

Iguchi, N., \& Ikeda, T. (2005). Effects of temperature on metabolism, growth and growth efficiency of Thysanoessa longipes (Crustacea: Euphausiacea) in the Japan Sea. Journal of Plankton Research, 27, 1-10. https://doi.org/10.1093/plankt/lbh146

Jang, E. B. (1991). Thermal death kinetics and heat tolerance in early and late 3rd instars of the oriental fruit fly (Diptera, Tephritidae). Journal of Economic Entomology, 84, 1298-1303. https://doi.org/10.1093/ jee/84.4.1298

Janhunen, M., Piironen, J., \& Peuhkuri, N. (2010). Parental effects on embryonic viability and growth in Arctic charr Salvelinus alpinus at two incubation temperatures. Journal of Fish Biology, 76, 2558-2570. https://doi.org/10.1111/j.1095-8649.2010.02648.x

Jann, P., \& Ward, P. I. (1999). Maternal effects and their consequences for offspring fitness in the Yellow Dung Fly. Functional Ecology, 13, 51-58. https://doi.org/10.1046/j.1365-2435.1999.00269.x

Janzen, F. J. (1993). An experimental analysis of natural selection on body size of hatchling turtles. Ecology, 74, 332-341. https://doi. org/10.2307/1939296

Karl, T. R., \& Trenberth, K. E. (2003). Modern global climate change. Science, 302, 1719-1723. https://doi.org/10.1126/scien ce.1090228

Kirtman, B., Power, S. B., Adedoyin, J. A., Boer, G. J., Bojariu, R., Camilloni, I., \& Wang, H. J. (2013). Near-term climate change: Projections and predictability. In T. F. Stocker, D. Qin, G.-K. Plattner, M. M. B. Tignor, S. K. Allen, J. Boschung, A. Nauels, Y. Xia, V. Bex \& P. M. Midgley (Eds.), Climate change 2013: The physical science basis. Contribution of working group I to the fifth assessment report of the Intergovernmental Panel on Climate Change. Summary for policy makers (pp. 953-1028). Cambridge and New York: Cambridge University Press.

Klockmann, M., Günter, F., \& Fischer, K. (2017). Heat resistance throughout ontogeny: Body size constrains thermal tolerance. Global Change Biology, 23, 686-696. https://doi.org/10.1111/gcb.13407

Krist, M. (2011). Egg size and offspring quality: A meta-analysis in birds. Biological Reviews, 86, 692-716. https://doi. org/10.1111/j.1469-185x.2010.00166.x

Langeloh, L., Behrmann-Godel, J., \& Seppälä, O. (2017). Natural selection on immune defense: A field experiment. Evolution, 71, 227-237. https ://doi.org/10.1111/evo.13148

Leicht, K., Jokela, J., \& Seppälä, O. (2013). An experimental heat wave changes immune defense and life history traits in a freshwater snail. Ecology and Evolution, 3, 4861-4871. https://doi.org/10.1002/ ece 3.874

Leicht, K., Jokela, J., \& Seppälä, O. (2019). Inbreeding does not alter the response to an experimental heat wave in a freshwater snail. PLoS ONE, 14, e0220669.

Leicht, K., Seppälä, K., \& Seppälä, O. (2017). Potential for adaptation to climate change: Family-level variation in fitness-related traits and their responses to heat waves in a snail population. BMC Evolutionary Biology, 17, 140. https://doi.org/10.1186/s12862-017-0988-x
Levitan, D. R. (2000). Optimal egg size in marine invertebrates: Theory and phylogenetic analysis of the critical relationship between egg size and development time in echinoids. American Naturalist, 156, 175-192. https://doi.org/10.1086/303376

Marshall, D. J. (2008). Transgenerational plasticity in the sea: Contextdependent maternal effects across the life history. Ecology, 89, 418427. https://doi.org/10.1890/07-0449.1

McCormick, M. I. (1999). Experimental test of the effect of maternal hormones on larval quality of a coral reef fish. Oecologia, 118, 412-422. https://doi.org/10.1007/s004420050743

Meehl, G. A., \& Tebaldi, C. (2004). More intense, more frequent, and longer lasting heat waves in the 21st century. Science, 305, 994-997. https://doi.org/10.1126/science.1098704

Miller, G. M., Watson, S.-A., Donelson, J. M., McCormick, M. I., \& Munday, P. L. (2012). Parental environment mediates impacts of increased carbon dioxide on a coral reef fish. Nature Climate Change, 2, 858-861. https://doi.org/10.1038/nclimate1599

Mitchell, S. E., \& Read, A. F. (2005). Poor maternal environment enhances offspring disease resistance in an invertebrate. Proceedings of the Royal Society B: Biological Sciences, 272, 2601-2607. https://doi. org/10.1098/rspb.2005.3253

Moran, A. L., \& Woods, H. A. (2007). Oxygen in egg masses: Interactive effects of temperature, age, and egg-mass morphology on oxygen supply to embryos. Journal of Experimental Biology, 210, 722-731. https://doi.org/10.1242/jeb.02702

Moret, Y. (2006). 'Trans-generational immune priming': Specific enhancement of the antimicrobial immune response in the mealworm beetle, Tenebrio molitor. Proceedings of the Royal Society of London Series B: Biological Sciences, 273, 1399-1405. https://doi.org/10.1098/ rspb.2006.3465

Mousseau, T. A., \& Dingle, H. (1991). Maternal effects in insect life histories. Annual Review of Entomology, 36, 511-534. https://doi. org/10.1146/annurev.en.36.010191.002455

Mousseau, T. A., \& Fox, C. W. (1998a). The adaptive significance of maternal effects. Trends in Ecology \& Evolution, 13, 403-407. https://doi. org/10.1016/s0169-5347(98)01472-4

Mousseau, T. A., \& Fox, C. W. (1998b). Maternal effects as adaptations. New York: Oxford University Press.

Nakadera, Y., Blom, C., \& Koene, J. M. (2014). Duration of sperm storage in the simultaneous hermaphrodite Lymnaea stagnalis. Journal of Molluscan Studies, 80, 1-7. https://doi.org/10.1093/mollus/eyt049

Nakadera, Y., Mariën, J., Van Straalen, N. M., \& Koene, J. M. (2017). Multiple mating in natural populations of a simultaneous hermaphrodite, Lymnaea stagnalis. Journal of Molluscan Studies, 83, 56-62. https ://doi.org/10.1093/mollus/eyw043

Noble, D. W. A., Stenhouse, V., \& Schwanz, L. E. (2018). Developmental temperatures and phenotypic plasticity in reptiles: A systematic review and meta-analysis. Biological Reviews, 93, 72-97. https://doi. org/10.1111/brv.12333

Parker, L. M., Ross, P. M., O'Connor, W. A., Borysko, L., Raftos, D. A., \& Portner, H.-O. (2012). Adult exposure influences offspring response to ocean acidification in oysters. Global Change Biology, 18, 82-92. https://doi.org/10.1111/j.1365-2486.2011.02520.x

Parmesan, C., \& Yohe, G. (2003). A globally coherent fingerprint of climate change impacts across natural systems. Nature, 421, 37-42. https://doi.org/10.1038/nature01286

Pepin, P. (1991). Effect of temperature and size on development, mortality, and survival rates of the pelagic early life history stages of marine fish. Canadian Journal of Fisheries and Aquatic Sciences, 48, 503-518. https://doi.org/10.1139/f91-065

Person-Le Ruyet, J., Mahé, K., Le Bayon, N., \& Le Delliou, H. (2004). Effects of temperature on growth and metabolism in a Mediterranean population of European sea bass, Dicentrarchus labrax. Aquaculture, 237, 269-280. https://doi.org/10.1016/j.aquac ulture.2004.04.021 
Pettay, J. E., Charmantier, A., Wilson, A. J., \& Lummaa, V. (2008). Age-specific genetic and maternal effects in fecundity of preindustrial Finnish women. Evolution, 62, 2297-2304. https://doi. org/10.1111/j.1558-5646.2008.00452.x

Pörtner, H. O., Lucassen, M., \& Storch, D. (2005). Metabolic biochemistry: Its role in thermal tolerance and in the capacities of physiological and ecological function. In J. F. Steffensen, A. P. Farrell, W. S. Hoar, \& D. R. Randall (Eds.), The physiology of polar fishes (fish physiology 21) (pp. 79-154). San Diego: Elsevier Academic Press.

Puurtinen, M., Knott, K. E., Suonpää, S., Nissinen, K., \& Kaitala, V. (2007). Predominance of outcrossing in Lymnaea stagnalis despite low apparent fitness costs of self-fertilization. Journal of Evolutionary Biology, 20, 901-912. https://doi.org/10.1111/j.1420-9101.2007.01312.x

Saino, N., Romano, M., Ambrosini, R., Ferrari, R. P., \& Møller, A. P. (2004). Timing of reproduction and egg quality covary with temperature in the insectivorous Barn Swallow, Hirundo rustica. Functional Ecology, 18, 50-57. https://doi.org/10.1046/j.0269-8463.2004.00808.x

Salinas, S., \& Munch, S. B. (2012). Thermal legacies: Transgenerational effects of temperature on growth in a vertebrate. Ecology Letters, 15, 159-163. https://doi.org/10.1111/j.1461-0248.2011.01721.x

Salo, T., Stamm, C., Burdon, F. J., Räsänen, K., \& Seppälä, O. (2017). Resilience to heat waves in the aquatic snail Lymnaea stagnalis: Additive and interactive effects with micropollutants. Freshwater Biology, 62, 1831-1846. https://doi.org/10.1111/fwb.12999

Seppälä, O., \& Jokela, J. (2011). Immune defence under extreme ambient temperature. Biology Letters, 7, 119-122. https://doi.org/10.1098/ rsbl.2010.0459

Seppälä, O., \& Leicht, K. (2013). Activation of the immune defence of the freshwater snail Lymnaea stagnalis by different immune elicitors. Journal of Experimental Biology, 216, 2902-2907. https://doi. org $/ 10.1242 /$ jeb.084947

Shama, L. N. S., Strobel, A., Mark, F. C., \& Wegner, K. M. (2014). Transgenerational plasticity in marine sticklebacks: Maternal effects mediate impacts of a warming ocean. Functional Ecology, 28, 14821493. https://doi.org/10.1111/1365-2435.12280

Sibert, V., Ouellet, P., \& Brêthes, J. C. (2004). Changes in yolk total proteins and lipid components and embryonic growth rates during lobster (Homarus americanus) egg development under a simulated seasonal temperature cycle. Marine Biology, 144, 1075-1086. https:// doi.org/10.1007/s00227-003-1287-1

Silbermann, R., \& Tatar, M. (2000). Reproductive costs of heat shock protein in transgenic Drosophila melanogaster. Evolution, 54, 2038-2045. https://doi.org/10.1554/0014-3820(2000) 054 [2038:RCOHSP]2.0.CO;2

Steer, M. A., Moltschaniwskyj, M. A., Nichols, D. S., \& Miller, M. (2004). The role of temperature and maternal ration in embryo survival: Using the dumpling squid Euprymna tasmanica as a model. Journal of Experimental Marine Biology and Ecology, 307, 73-89. https://doi. org/10.1016/j.jembe.2004.01.017

Steigenga, M. J., \& Fischer, K. (2007). Within- and between-generation effects of temperature on life-history traits in a butterfly. Journal of Thermal Biology, 32, 396-405. https://doi.org/10.1016/j.jther bio.2007.06.001

Stillman, J. H. (2019). Heat waves, the new normal: Summertime temperature extremes will impact animals, ecosystems, and human communities. Physiology, 34, 86-100. https://doi.org/10.1152/physi ol.00040.2018

Tessier, A. J., Henry, L. L., Goulden, C. E., \& Durand, M. W. (1983). Starvation in Daphnia: Energy reserves and reproductive allocation. Limnology and Oceanography, 28, 667-676. https://doi.org/10.4319/ lo.1983.28.4.0667
Uller, T., \& Olsson, M. (2010). Offspring size and timing of hatching determine survival and reproductive output in a lizard. Oecologia, 162, 663-671. https://doi.org/10.1007/s00442-009-1503-x

Vaughn, C. M. (1953). Effects of temperature on hatching and growth of Lymnaea stagnalis appressa Say. American Midland Naturalist, 49, 214-228. https://doi.org/10.2307/2422289

Wadgymar, S. M., Mactavish, R. M., \& Anderson, J. T. (2018). Transgenerational and within-generation plasticity in response to climate change: Insights from a manipulative field experiment across an elevational gradient. American Naturalist, 192, 698-714. https://doi. org/10.1086/700097

Walther, G.-R. (2010). Community and ecosystem responses to recent climate change. Philosophical Transactions of the Royal Society B: Biological Sciences, 365, 2019-2024. https://doi.org/10.1098/ rstb.2010.0021

Walther, G.-R., Post, E., Convey, P., Menzel, A., Parmesan, C., Beebee, T. J. C., \& Bairlein, F. (2002). Ecological responses to recent climate change. Nature, 416, 389-395. https://doi.org/10.1038/416389a

Warkentin, K. M. (1995). Adaptive plasticity in hatching age: A response to predation risk trade-offs. Proceedings of the National Academy of Sciences of the United States of America, 92, 3507-3510. https://doi. org/10.1073/pnas.92.8.3507

Warkentin, K. M. (1999). Effects of hatching age on development and hatchling morphology in the red-eyed treefrog, Agalychnis callidryas. Biological Journal of the Linnean Society, 68, 443-470. https://doi. org/10.1006/bijl.1999.0325

Warner, D. A., \& Shine, R. (2007). Fitness of juvenile lizards depends on seasonal timing of hatching, not offspring body size. Oecologia, 154, 65-73. https://doi.org/10.1007/s00442-007-0809-9

Williams, G. C. (1966). Natural selection costs of reproduction and a refinement of Lack's principle. American Naturalist, 100, 687-690. https://doi.org/10.1086/282461

Williams, T. D. (1994). Intraspecific variation in egg size and egg composition in birds: Effects on offspring fitness. Biological Reviews of the Cambridge Philosophical Society, 69, 35-59. https://doi.org/10.1111/ j.1469-185x.1994.tb01485.x

Woods, H. A. (1999). Egg-mass size and cell size: Effects of temperature on oxygen distribution. American Zoologist, 39, 244-252. https://doi. org/10.1093/icb/39.2.244

Yampolsky, L. Y., \& Scheiner, S. M. (1996). Why larger offspring at lower temperatures? A demographic approach. American Naturalist, 147, 86-100. https://doi.org/10.1086/285841

Zhang, W., Chang, X.-Q., Hoffmann, A. A., Zhang, S., \& Ma, C.-S. (2015). Impact of hot events at different developmental stages of a moth: The closer to adult stage, the less reproductive output. Scientific Reports, 5, 10436. https://doi.org/10.1038/srep10436

Zuo, W. Y., Moses, M. E., West, G. B., Hou, C., \& Brown, J. H. (2012). A general model for effects of temperature on ectotherm ontogenetic growth and development. Proceedings of the Royal Society B: Biological Sciences, 279, 1840-1846. https://doi.org/10.1098/ rspb.2011.2000

How to cite this article: Leicht K, Seppälä O. Direct and transgenerational effects of an experimental heatwave on early life stages in a freshwater snail. Freshw Biol. 2019;64:2131-2140. https://doi.org/10.1111/fwb.13401 